\title{
Evaluating the muscular strength, functional capacity, and risk of sarcopenia in elderly women who practice Mat Pilates
}

\author{
Avaliação da força muscular, capacidade funcional e indicativo \\ de sarcopenia em idosas que praticam Pilates no solo
}

\author{
Evaluación de la fuerza muscular, capacidad funcional \\ $e$ indicativo de sarcopenia en mujeres de edad \\ avanzada que practican Pilates en el suelo
}

Daniel Vicentini de Oliveira ${ }^{[a]}$, Amanda Mansano de Souza ${ }^{[a]}$, Áurea Gonçalves Ferreira ${ }^{[b]}$, Mateus Dias Antunes ${ }^{[c]}$, Natália Serra Lovato ${ }^{[d]}$, José Roberto Andrade do Nascimento Júnior $\left.\circledast\right]^{*}$

\footnotetext{
[a] Centro Universitário Metropolitano de Maringá (Unifamma), Maringá, PR, Brazil

[b] Universidade Estadual de Campinas (Unicamp), Campinas, SP, Brazil

[c] Universidade de São Paulo (USP), São Paulo, SP, Brazil

[d] Universidade Estadual de Londrina (UEL), Londrina, PR, Brazil

[e] Universidade Federal do Vale do São Francisco (Univasf), Petrolina, PE, Brazil
}

\begin{abstract}
Introduction: Despite the importance of appropriate levels of muscular strength to maintain the functional capacity and a healthy life in old age, the current literature still lacks studies that investigate the profile of elderly women who practice Mat Pilates regarding these variables. Objective: This study aimed to analyze
\end{abstract}

\footnotetext{
* DVO: PhD, email: d.vicentini@hotmail.com AMS: BS, email: souzamanda@hotmail.com AGF: MS, email: aurea_fisio@hotmail.com MDA: PhD, email: mateus_antunes03@hotmail.com NSL: MS, email: natalia_lovato@hotmail.com JRANJ: PhD, email: jroberto.jrs01@gmail.com
} 
muscular strength, functional capacity, and risk of sarcopenia in elderly women who practiced Mat Pilates. Method: This is a cross-sectional study carried out with 50 elderly women who practice Mat Pilates in the city of Maringá, Paraná. Sociodemographic and health questionnaires were used, in addition to tests created by a Latin American development group for maturity called Grupo de Desenvolvimento Latino Americano para a Maturidade (GDLAM), sitting-rising test, arm curl test, and SARC-F questionnaire. For data analysis, ShapiroWilk and Mann-Whitney U tests, as well as Spearman's Rank Correlation Coefficients, were used. The level of significance was $p<0.05$. Results: The 70-79-year-old elderly women showed worse results in the functional capacity and muscular strength tests of the upper limbs and a higher risk of sarcopenia than the individuals who were under 70 years of age. Muscular strength was inversely related to the reduction of the risk of sarcopenia, and functional capacity was directly associated with this risk. Conclusion: A good functional capacity seems to be related to the reduction of the risk of sarcopenia. Age seems to be an intervening factor for reducing muscular strength levels and functional capacity and increasing the risk of sarcopenia.

Keywords: Muscular Strength. Functional Capacity. Old Age. Sarcopenia.

\section{Resumo}

Introdução: Apesar da importância de níveis adequados de força muscular para manter a capacidade funcional e uma vida saudável na velhice, a literatura atual ainda carece de estudos que investiguem o perfil de idosas que praticam o Pilates no solo em relação a essas variáveis. Objetivo: Este trabalho teve como objetivo investigar a força muscular, a capacidade funcional e o indicativo de sarcopenia em idosas praticantes de Pilates no solo. Método: Trata-se de um estudo transversal realizado com 50 idosas que praticam Pilates no solo na cidade de Maringá-PR. Utilizaram-se questionários sociodemográficos e de saúde, além de testes realizados pelo grupo de desenvolvimento latino-americano para maturidade do chamado Grupo de Desenvolvimento Latino-americano para a Maturidade (GDLAM), $p$ teste de levantar e sentar, teste de flexão de cotovelo e o Questionário SARC-F. Para análise dos dados, foram utilizados os testes Shapiro-Wilk e Mann-Whitney U, bem como os Coeficientes de Correlação de Spearman. 0 nível de significância foi estabelecido em $p<0,05$. Resultados: As idosas de 70 a 79 anos apresentaram piores resultados nos testes de capacidade funcional e força muscular dos membros superiores e maior indicativo de sarcopenia do que os indivíduos com menos de 70 anos de idade. A força muscular foi inversamente relacionada à redução do indicativo de sarcopenia, e a capacidade funcional esteve diretamente associada a esse indicativo. Conclusão: Uma boa capacidade funcional parece estar relacionada à redução do indicativo de sarcopenia. A idade parece ser um fator interveniente para reduzir os níveis de força muscular e a capacidade funcional, além de aumentar o indicativo de sarcopenia

Palavras-chave: Força Muscular. Capacidade Funcional. Velhice. Sarcopenia.

\section{Resumen}

Introducción: A pesar de la importancia de los niveles apropiados de fuerza muscular para mantener la capacidad funcional y una vida saludable en la vejez, la literatura actual aún carece de estudios que investiguen el perfil de las mujeres ancianas que practican Pilates en el suelo en relación con estas variables. Objetivo: Este trabajo tuvo como objetivo investigar la fuerza muscular, la capacidad funcional y el indicio de sarcopenia en mujeres ancianas que practican Pilates en el suelo. Método: Este es un estudio transversal realizado con 50 mujeres ancianas que practican Pilates en el suelo en la ciudad de Maringá-PR. Se utilizaron cuestionarios sociodemográficos y de salud, además de las pruebas realizadas por un grupo de desarrollo de América Latina para el llamado Grupo de Desarrollo Latino Americano para una Muerte (GDLAM), la prueba de aumento de la sesión, la prueba de flexión del brazo y la Cuestionario SARC-F. Para el análisis de los datos, se utilizaron las pruebas Shapiro-Wilky Mann-Whitney U, así como los coeficientes de correlación de rango de Spearman. El nivel de significación se estableció en $p<0.05$. Resultados: Las mujeres de 70 a 79 años de edad mostraron peores resultados en la capacidad funcional y las pruebas de fuerza muscular de las extremidades superiores y un mayor 
indicio de sarcopenia en comparación con las personas menores de 70 años. La fuerza muscular se relacionó inversamente con la reducción del indicativo de sarcopenia, y la capacidad funcional se asoció directamente con este indicativo. Conclusión: Una buena capacidad funcional parece estar relacionada con la reducción del indicativo de sarcopenia. La edad parece ser un factor que interviene para reducir los niveles de fuerza muscular y la capacidad funcional, y también para aumentar el indicativo de sarcopenia.

Palabras clave: Fuerza Muscular. Capacidad Funcional. Vejez. Sarcopenia.

\section{Introduction}

The aging process of the Brazilian population is similar to that of the world population, which, undoubtedly, can be considered a success for the country [1]. Aging has different manifestations and outcomes, including fragile, vulnerable, and dependent elderly people. Human muscular strength reaches its peak between the second and third decade of life, with a slow or unnoticeable decrease until the age of 50 . After 65 , muscular strength decreases with a rate of about 12 to $15 \%$ per decade. This negatively affects the functional capacity of older people [2]. Furthermore, another unfavorable consequence of the aging process is sarcopenia, which can be defined as the progressive loss of muscle mass associated with functional decline [3].

Sarcopenia can be classified as primary and secondary [4]. However, in practice, the etiology of sarcopenia tends to be multifactorial, which makes it difficult to be classified [4]. Treating sarcopenia includes several intervention strategies, such as suitable nutrition and dietary supplementation, but mainly the regular practice of physical exercises [3].

Regular physical exercises avoid the loss of muscle mass, in addition to promoting muscle growth and improving physical and cognitive functions, thus preventing functional decline [5]. Among the different physical exercise programs available to the elderly population, Pilates has become very popular $[1,5]$. Mat Pilates consists in doing exercises that usually require the individual's own body weight and the action of gravity as a form of endurance [6-8].

Despite the importance of appropriate levels of muscular mass and strength to maintain the balance and ability to move, as well as to prevent joint pain and, consequently, preserve a healthy life in old age, the current literature still lacks studies that investigate the profile of elderly women who practice Mat Pilates, mainly regarding muscular strength, functional capacity, the risk of sarcopenia, and the relationship between these variables. In view of the previously described benefits offered by such modality for several physical abilities, the hypothesis of this study is that elderly women who practice Mat Pilates show good muscular strength and functional capacity, as well as a low risk of sarcopenia.

No studies were found in the scientific literature showing the interrelation of strength, functional capacity, and risks of sarcopenia between elderly people who practice Mat Pilates and those who do not.

Therefore, this study aimed to analyze muscular strength, functional capacity, and the risk of sarcopenia in elderly women who practice Mat Pilates, in addition to compare the variables according to their age group and assess their correlation.

\section{Methods}

Subjects

This cross-sectional study was carried out by using a nonprobability convenience sampling that comprised 50 women with an average age of $65.9 \pm$ 5.2 years. The study included elderly women aged 60 and older with preserved speech, expression, and understanding skills, who practiced Mat Pilates in one of the fitness centers in the city of Maringá, state of Paraná. Men were not included because this modality is predominantly practiced by women.

The Mini Mental State Examination (MMSE) was used to exclude the elderly women with possible cognitive deficits. It consists of questions grouped into seven categories: temporal orientation, spatial orientation, three-word register, attention and 
calculation, recall of the three words, language, and visual constructive ability [9]. The cut-off points used for exclusion by the MMSE were: 17 for the illiterate; 22 for the elderly with 1-4 years education level; 24 for those with 5-8 years education level; and 26 for the subjects who had studied for 9 years or longer. These cut-off points were based on the criteria of Brucki et al. [10], which correspond to the average obtained by these authors for each education level, minus one standard deviation. The elderly women who were classified under the cut-off point specific for their education level were excluded.

\section{Instruments}

A semistructured questionnaire was used to characterize the elderly women, consisting of questions related to age, ethnicity, education, smoking habits, retirement benefits, monthly income, marital status, occupational situation (whether the individual works to have an income), presence of diseases, history of falls in the last six months, selfperceived health, self-perceived body image, reasons for doing Mat Pilates, length of time they have been doing Mat Pilates, number of times they practice Pilates per week, and whether they practice another physical exercise.

Functional capacity was assessed by applying a functional autonomy battery of tests created by GDLAM $[11,12]$, which included walking 10 meters (W10), rising from the sitting position (RSP), rising from the decubitus ventral position (RDVP), putting on and taking off the T-shirt (PTTS), rising from the sitting position and walking around the house (RSPWH). The tests were evaluated according to the time each of them lasted, in seconds. The shorter the time the tests are accomplished, the better the result is (weak, regular, good, very good). All the tests were used to obtain the general autonomy index (GI) by GDLAM. The lower scores obtained represent a better level of functional capacity. The GI was calculated as follows:

$$
\frac{\mathrm{GI}=[(\mathrm{W} 10+\mathrm{RSP}+\mathrm{RDVP}+\mathrm{PTTS} \times 2]+\mathrm{RSPWH}}{4}
$$

To examine the strength of the lower limbs (LLs) and upper limbs (ULs), the sitting-rising test and the Arm Curl Test were used; both are part of the Senior Fitness Test (SFT).
Considering the sitting-rising test, each woman was told to sit and rise from a chair with arms folded across the chest. A chair 45 centimeters high from the floor to the seat was used. The elderly should complete as many actions as possible in 30 seconds. Regarding the Arm Curl Test, the individual should remain seated at the edge of the chair and hold a $2 \mathrm{~kg}$ alter with her dominant hand, performing as many actions as possible in 30 seconds. The evaluator pressed his/her fingers on the middle of the elderly woman's arm, encouraging her to perform several actions. The results of both tests were classified as very weak, weak, regular, good, and very good [13].

To analyze the risks of sarcopenia, the SARC-F questionnaire was applied. This test diagnoses sarcopenia according to five components: strength, assistance with walking, rising from the sitting position, climbing stairs, and falls. The scores range from 0 to 10, with 0 to 2 points for each component, that is, SARC-F $<4$ (without risks of sarcopenia) and SARC-F $\geq 4$ (with risks of sarcopenia) [14].

\section{Data collection}

At first, the Secretary for Sports (SESP) of the municipality of Maringá, Paraná, was contacted to obtain authorization to carry out the research. The study was then approved by the Standing Committee on Ethical Research with Humans of the Faculdade Metropolitana de Maringá (FAMMA) under protocol 2.091.893/2017.

The study followed the guidelines for research with humans under Opinion No 466/12 of the National Council on Health. All the elderly women signed the Free Informed Consent Form (FICF).

\section{Data analysis}

Regarding data analysis, frequency and percentage were used for the categorical variables. For the numerical variables, at first the normality of the data was verified by using Shapiro-Wilk test. Since the data did not show a normal distribution, Median (Md) and Quartiles (Q1; Q3) were used to characterize the results. For comparing muscle strength, functionality, and risk of sarcopenia according to age, MannWhitney U test was used. The correlation between the variables was assessed by using Spearman's correlation test. A significance level of $\mathrm{p}<0.05$ was considered. 


\section{Results}

There was a prevalence of elderly women who did not have a partner $(60.0 \%)$, aged between 60 and 69 years $(78.0 \%)$, with a monthly income from 1 to 2 minimum wages (58.0\%), white (80.0\%), inactive (64.0\%), and retired (72.0\%). Most subjects had finished elementary education (58.0\%).

Regarding the health and physical activity profile (Table 1), most elderly women reported no disease (72.0\%), not having fallen in the past six months (80.0\%), having been practicing Mat Pilates due to medical recommendation (42.0\%), and having been practicing another exercise besides this modality (56.0\%). Most elderly women had been practicing Mat Pilates for a period between six months and two years $(52.0 \%)$ and had a frequency of one to two times a week (86.0\%).

Table 1 - Health and physical activity profile of the elderly women who practice Mat Pilates in Maringá/PR

\begin{tabular}{lcc}
\hline Variables & $f$ & $\%$ \\
\hline Number of diseases & 36 & 72.0 \\
$\quad$ None & 11 & 22.0 \\
1 & 3 & 6.0 \\
2 or more & & \\
$\quad$ History of falls & 10 & 20.0 \\
Yes & 40 & 80.0 \\
$\quad$ No & & \\
Practice another exercise & 28 & 56.0 \\
$\quad$ Yes & 22 & 44.0 \\
$\quad$ No & & \\
Practice time & 19 & 38.0 \\
Less than 6 months & 26 & 52.0 \\
$\quad 6$ months to 2 years & 5 & 10.0 \\
$\quad$ More than 2 years & & \\
Weekly frequency & 43 & 86.0 \\
1 to 2 times & 7 & 14.0 \\
3 times or more & & \\
\hline
\end{tabular}

Considering the muscle strength analysis (Table 2 ), it was found that the elderly women had a weak level prevalence for the muscle strength of the LLs (sitting-rising test in 30 seconds) (54.0\%), but good muscle strength of the ULs (arm curl test) (94.0\%). The following tests performed to evaluate the functional capacity showed a weak level prevalence: W10 (88.0\%), RSPWH (94.0\%), RDVP (100.0\%). Regarding the GI of the functional capacity, $90 \%$ of the elderly women presented a weak level. Concerning sarcopenia, $96.0 \%$ of the elderly women had no risk of developing it.

Table 2 - Level of functional and muscular strength of the elderly women who practice Mat Pilates in Maringá/PR

\begin{tabular}{|c|c|c|}
\hline Variables & $f$ & $\%$ \\
\hline \multicolumn{3}{|c|}{ LLs Muscular strength } \\
\hline Weak & 27 & 54.0 \\
\hline Regular & 17 & 34.0 \\
\hline Good & 6 & 12.0 \\
\hline \multicolumn{3}{|c|}{ ULs Muscular strength } \\
\hline Weak & 2 & 4.0 \\
\hline Regular & 1 & 2.0 \\
\hline Good & 47 & 94.0 \\
\hline \multicolumn{3}{|l|}{ W10 } \\
\hline Weak & 44 & 88.0 \\
\hline Regular & 5 & 10.0 \\
\hline Good & 1 & 2.0 \\
\hline \multicolumn{3}{|l|}{ RSP } \\
\hline Weak & 23 & 46.0 \\
\hline Regular & 16 & 32.0 \\
\hline Good & 11 & 22.0 \\
\hline \multicolumn{3}{|l|}{ RSPWH } \\
\hline Weak & 47 & 94.0 \\
\hline Regular & 3 & 6.0 \\
\hline Good & 0 & 0.0 \\
\hline \multicolumn{3}{|l|}{ RDVP } \\
\hline Weak & 50 & 100.0 \\
\hline Regular & 0 & 0.0 \\
\hline Good & 0 & 0.0 \\
\hline \multicolumn{3}{|l|}{ PTTS } \\
\hline Weak & 0 & 0.0 \\
\hline Regular & 0 & 0.0 \\
\hline Good & 50 & 100.0 \\
\hline \multicolumn{3}{|l|}{ GI } \\
\hline Weak & 45 & 90.0 \\
\hline Regular & 5 & 10.0 \\
\hline Good & 0 & 0.0 \\
\hline \multicolumn{3}{|c|}{ Risk of sarcopenia } \\
\hline Yes & 2 & 4.0 \\
\hline No & 48 & 96.0 \\
\hline
\end{tabular}

Note: LLs: lower limbs; Uls: upper limbs; W10: walking 10 meters; RSP: rising from the sitting position; RSPWH: rising from the sitting position and walking around the house; RDVP: rising from the decubitus ventral position; PTTS: putting on and taking off the T-shirt; Gl: general index (GDLAM).

When comparing the muscle strength of the elderly women according to their age group (Table 3), a significant difference was found between the groups only in the arm curl test $(p=0.002)$. Considering functional capacity, a 
significant difference was found in the following tests: $\operatorname{RSP}(p=0.017)$, RSPWH ( $p=0.008)$, RDVP ( $=0.001)$, and GI $(p=0.001)$. The risk of sarcopenia was also different according to age $(\mathrm{p}=0.012)$.

Table 3 - Comparison of muscle strength and functional capacity of the elderly women who practice Mat Pilates in the city of Maringá/PR, according to their age group

\begin{tabular}{|c|c|c|c|}
\hline \multirow[t]{3}{*}{ Variables } & \multicolumn{2}{|c|}{ Age Group } & \multirow{3}{*}{$P$} \\
\hline & $60-69$ years $(n=39)$ & $70-79$ years $(n=11)$ & \\
\hline & Md $(Q 1 ; Q 3)$ & Md $(Q 1 ; Q 3)$ & \\
\hline \multicolumn{4}{|l|}{ Muscular strength } \\
\hline Sitting-rising test & $15.0(13.0 ; 16.0)$ & $13.0(13.0 ; 15.0)$ & 0.093 \\
\hline Arm curl test & $25.0(22.0 ; 26.0)$ & $21.0(15.0 ; 13.0)$ & $0.002^{*}$ \\
\hline \multicolumn{4}{|l|}{ Functional capacity } \\
\hline 10-minute walking & $8.4(7.6 ; 9.3)$ & $8.4(8.3 ; 9.6)$ & 0.393 \\
\hline Rising from the sitting position & $10.6(9.5 ; 12.0)$ & $12.4(11.0 ; 13.7)$ & $0.017^{*}$ \\
\hline Rising from the sitting position and walking around the house & $50.1(47.4 ; 52.3)$ & $53.3(50.7 ; 56.2)$ & $0.008^{*}$ \\
\hline Rising from the decubitus ventral position & $7.1(6.3 ; 8.1)$ & $9.3(8.3 ; 10.6)$ & $0.001^{*}$ \\
\hline Putting on and taking off the T-shirt & $7.8(6.4 ; 9.1)$ & $8.9(6.3 ; 10.2)$ & 0.308 \\
\hline General index of functional capacity & $29.1(28.1 ; 30.5)$ & $32.5(31.5 ; 33.8)$ & $0.001^{*}$ \\
\hline \multirow[t]{2}{*}{ Risk of sarcopenia } & & & \\
\hline & $1.0(1.0 ; 2.0)$ & $2.0(1.0 ; 3.0)$ & $0.012^{\star}$ \\
\hline
\end{tabular}

Note: *Significant difference: $p<0.05$ - Mann-Whitney U Test.

Table 4 shows that the risk of sarcopenia had significant correlations $(\mathrm{p}<0.05)$ and weak ones $(\mathrm{r}<0.40)$ with the muscle strength of the LLs $(\mathrm{r}=$ 0.33 ) and ULs ( $r=-0.61)$; and also with the functional capacity in the RSP $(\mathrm{r}=0.32)$, RSPWH ( $\mathrm{r}=0.33)$, RDVP $(\mathrm{r}=0.45)$, and GI $(\mathrm{r}=0.58)$ tests. These results show that the muscular strength is inversely related to the reduction of the risk of sarcopenia. In addition, the results of the functional capacity tests are directly associated with this risk, that is, the worse the results of the functional capacity tests, the higher the risk of sarcopenia; however, such relationships were weak.

Table 4 - Correlation between functional capacity, muscular strength, and risk of sarcopenia of the elderly women

\begin{tabular}{|c|c|c|c|c|c|c|c|c|c|}
\hline \multirow{2}{*}{ Variables } & \multicolumn{2}{|c|}{ Muscular strength } & \multicolumn{6}{|c|}{ Functional capacity } & \multirow{2}{*}{$\begin{array}{c}\text { R. } \\
\text { Sarcopenia }\end{array}$} \\
\hline & SLLS & SULS & W10M & RSP & RSPWH & RDVP & PTTS & GI & \\
\hline SLLS & & $0.28^{\star}$ & -0.25 & -0.13 & -0.25 & -0.25 & $-0.32^{*}$ & $-0.45^{\star}$ & $-0.33^{*}$ \\
\hline SULS & & & -0.07 & $-0.33^{\star}$ & -0.24 & -0.26 & -0.22 & $-0.45^{\star}$ & $-0.61^{\star}$ \\
\hline W10 & & & & 0.12 & 0.10 & 0.19 & 0.24 & $0.50^{*}$ & 0.09 \\
\hline RSP & & & & & 0.24 & 0.25 & -0.20 & $0.57^{*}$ & $0.32^{*}$ \\
\hline RSPWH & & & & & & 0.19 & -0.11 & $0.57^{*}$ & $0.33^{*}$ \\
\hline RDVP & & & & & & & 0.07 & $0.67^{*}$ & $0.45^{\star}$ \\
\hline PTTS & & & & & & & & $0.34^{*}$ & 0.25 \\
\hline $\begin{array}{l}\text { R. } \\
\text { Sarcopenia }\end{array}$ & & & & & & & & & \\
\hline
\end{tabular}

Note: *Significant Correlation: $p<0.05$. SLLs: strength of lower limbs; SULs: strength of upper limbs; W10: walking 10 meters; RSP: rising from the sitting position; RSPWH: rising from the sitting position and walking around the house; RDVP: rising from the decubitus ventral position; PTTS: putting on and taking off the T-shirt; Gl: general index by GDLAM; R.: risk.

\section{Discussion}

According to the main findings of this study, the age of the elderly women who practice Mat Pilates is strongly associated with the loss of functional capacity; moreover, the muscle strength is negatively correlated with the risk of sarcopenia, whereas functional capacity is positively correlated with it.

This study showed that 70-79 year-old women obtained worse results regarding the strength levels in the LLs in most functional capacity tests (RSP, RCWH, RDVP), as well as in the GI of the functional 
capacity, in addition to the risk of sarcopenia, compared to 60-69 year-old individuals (Table 3), which confirms the results found in other researches [15-17]. A cross-sectional study carried out with 345 elderly subjects aged between 60 and 94 years, who lived in the urban area of a city in the south of Brazil, found that some variables, such as age over or equal to 70 years; the fact of being female; and having an economic status considered as reasonable, poor, or very poor, were positively associated with an inappropriate functional capacity [16].

Several investigations have also shown that agerelated loss of muscle mass, strength, and endurance are determining factors in the functional capacity of elderly people [18-22]. Thus, this loss interferes with several daily life tasks, such as those shown in this study; that is, rising from the sitting position, rising from the sitting position and walking around the house, rising from the decubitus ventral position, in addition to the general autonomy index.

A study by Reid et al. with 57 sedentary elderly individuals of both sexes and an average age of 74.2 years verified the influence of mass and muscle strength on functional capacity [19]. As a conclusion, the authors point out that both preservation and increase of muscle mass have a significant and independent effect on the strength preservation and, consequently, on the functional capacity of this population [19]. Furthermore, the authors showed that each kilogram $(\mathrm{kg})$ of increased lean body mass reduces in $53 \%$ the chance of the elderly to have serious functional limitations [19].

This study showed that most of the elderly women assessed had a low level of muscular strength for the LLs and poor performance in all functional capacity tests, despite being Mat Pilates practitioners. However, physical exercise is still considered an important intervention for preserving and increasing muscular strength and maintaining functional capacity [23-25].

Akune et al. carried out a study with 1000 Japanese older people. The authors showed that the elderly, who had been practicing physical exercises since middle age, had a low prevalence of sarcopenia and improvement of walking. Therefore, the researchers suggested that the habit of doing physical exercise is a protective factor that inhibits the development of sarcopenia and is effective for maintaining the muscle strength and physical capacity of the elderly [23].

Results related to the increase of muscle strength and mass were also verified in other investigations that used Mat Pilates exercises. This modality can significantly increase the muscle mass and strength of people because it promotes exercises that make them use only their own body weight $[5,26$, 27]. A study by Queiroz et al. , which evaluated the muscle mass of 43 elderly women with an average age of 73 years during 11 weeks, showed that 43 sessions of Mat Pilates, with a gradual increase in intensity, were enough to generate a positive effect on increasing muscle mass in elderly people [25]. Moreover, the age group of elderly individuals who are 70 years old or over showed a higher percentage of subjects with appropriate muscle mass after the intervention, unlike this study, in which the 70-79 age group showed a lower strength in the arm curl test, compared to the 60-69 age group.

A hypothesis that might justify the different results found in out study may be the absence of control and analysis of the influence of some variables, that is, frequency, duration, intensity of the sessions of Pilates, as well as the time each elderly woman had been practicing Pilates or another physical exercise. In addition, this is an observational study, not an experimental one, which prevents the authors from assessing the relationships between cause and effect.

Another relevant fact is that the muscle mass decreases by approximately $2 \%$ every year after the age of 50. After that, there is also a reduction of about $15 \%$ of the muscle strength every 10 years [28]. Considering this, it is possible to infer that the same exercise generates different physiological muscle responses in 60-69 year-old and 70-79 yearold elderly women.

Regarding the arm curl test, $94 \%$ of the elderly women showed good results for muscle strength of the upper limbs (Table 3), which corroborates the results found in the study carried out in Florianópolis/SC in a program entitled 'Active Living'. Such investigation applied the strength test of the upper and lower limbs in elderly women who either had done functional gymnastics before or not, and showed a significant increase in muscle strength of the upper limbs in $90 \%$ of the elderly women who had started functional gymnastics [29]. However, the sitting-rising test of this study showed weak levels, whereas in the study carried out in Florianópolis the subjects reached $96 \%$ above the average for muscle strength of the lower limbs [29]. A study carried out in the city of Caxias do Sul/RS, which compared elderly women who practiced weight training and water aerobics with 
non-practitioners, showed no statistically significant difference between the two groups according to the sitting-rising test [30].

Another study also carried out in Paraná, with 30 elderly women, showed improvement of muscle strength and ULs functionality in the group submitted to the arm curl test, compared to non-practitioners. This corroborates our study, which showed good results (Table 3) in the arm curl test [31]. Regarding the analysis of functionality, there was a prevalence of all the weak levels. However, an intervention study performed with a dance group in community fitness centers in the city of Teresina/PI observed a significant improvement in functionality in all the elderly women after the beginning of Pilates practice, but no significant difference compared to before and after the intervention [32].

A study carried out in the city of Ipiaú/BA, with elderly women with an average age of 71 years, compared Pilates with endurance exercises. The results showed no statistical difference in either group and concluded that both physical activities were similar to the impact that occurs when either walking or being in balance position [33,34].

Considering the functional capacity test, a directly associated sarcopenia was found in this study. Another investigation was carried out in the city of Brejinho de Nazaré/TO, which included 39 elderly female quilombolas (inhabitants of rural black communities who are descendants of enslaved Africans) with an average age of 63 years, and who used to practice physical activity. Such study assessed functional capacity according to the walking speed and hand grip strength tests; the risk of sarcopenia associated with their functional capacity was found in $7.69 \%$ of the individuals, corroborating our study, which identified the same risk in $4 \%$ of the elderly women.

The data found in this study, that is, muscular strength inversely related to the reduction of the risk of sarcopenia and functional capacity directly associated with this risk, express in results the definition of sarcopenia, which is nothing but the reduction of muscle volume associated with a reduced functionality and walking speed. Thus, these results reflect the findings of the systematic review carried out by Papa et al. [28].

This research has some limitations that can affect the results, including a low number of participants; an investigation limited to female subjects; the lack of a description of the exercises performed, the duration of the classes, and accurate data about the frequency of classes, in addition to information on the length of time that the women had been doing Pilates. Another limitation is the fact that this is an observational study, thus, its design does not allow a prior assessment of the subjects, that is, an evaluation of the elderly women before they started doing Mat Pilates by using the same instruments to verify whether there was any improvement after they started practicing this modality.

\section{Conclusion}

Finally, the good functional capacity of the elderly women who practice Mat Pilates seems to be related to the reduction of the risk of sarcopenia. However, age seems to be an intervening factor for reducing the levels of muscular strength and functional capacity, in addition to increasing the risks of sarcopenia. These findings can help physical education professionals and physical therapists to better understand the muscular response of their students/patients before the exercises suggested. The results might also encourage such professionals to search alternative modalities to complement Mat Pilates for reducing the risks of sarcopenia, even in the elderly over the age of 70 years.

\section{References}

1. Curi V, Vilaça J, Haas A, Fernandes H. Effects of 16-weeks of pilates on health perception and sleep quality among elderly women. Arch Gerontol Geriatr. 2018;74:118-22.

2. Lustosa LP, Silva JP, Coelho FM, Pereira DS, Parentoni AN, Pereira LS. Efeito de um programa de resistência muscular na capacidade funcional e na força muscular dos extensores do joelho em idosas pré-frágeis da comunidade: ensaio clínico aleatorizado do tipo crossover. Rev Bras Fisioter. 2011;15(4):318-24.

3. Cruz-Jentoft AJ, Landi F, Schneider SM, Zúñiga C, Arai $\mathrm{H}$, Boirie $\mathrm{Y}$, et al. Prevalence of and interventions for sarcopenia in ageing adults: a systematic review: report of the International Sarcopenia Initiative (EWGSOP and IWGS). Age Ageing. 2014;43(6):748-59. 
4. Argilés JM, Muscaritoli M. The three faces of sarcopenia. J Am Med Dir Assoc. 2016;17(6):471-2.

5. Engers PB, Rombaldi AJ, Portella EG, Silva MC. The effects of the pilates method in the elderly: a systematic review. Rev Bras Reumatol. 2016;56(4):352-65.

6. Pestana VS, Pestana AMS, Schinoni MI, Silva MC, Silva MC, Pestana VLP. Efeitos do Pilates solo e exercício resistido sobre a obesidade central e o índice de massa corpórea em idosos. Rev Ci Med Biol. 2012;11(2):218-23.

7. Fonsêca AMC, Gomes AC, Bezerra NMB, Guerra RO, Fregonesi GAF, Maciel ACC. Influência do método pilates na força muscular respiratória de idosas. Fisioter Bras. 2012;13(5):330-35.

8. Rodrigues BGS, Cader SA, Torres NVOB, Oliveira EM, Dantas EHM. Functional autonomy of elderly women practicing pilates. Fisioter Pesqui. 2010;17(4):300-5.

9. Folstein MF, Folstein SE, McHugh PR. "Mini-mental state": a practical method for grading the cognitive state of patients for the clinician. J Psychiatr Res. 1975;12(3):189-98.

10. Brucki SM, Nitrini R, Caramelli P, Bertolucci PHF, Okamoto IH. Sugestões para o uso do mini-exame do estado mental no Brasil. Arq Neuropsiquiatr. 2003;61(3B):777-81.

11. Vale RGS, Novaes JS, Dantas EHM. Efeitos do treinamento de força e de flexibilidade sobre a autonomia de mulheres senescentes. R Bras Ci e Mov. 2005;13(2):33-40.

12. Dantas EHM, Souza Vale RG. Protocolo GDLAM de avaliação da autonomia funcional. Fit Perf J. 2004(3):175-82.

13. Rikli R, Jones J. Teste de aptidão física para idosos. São Paulo: Manole; 2008.

14. Barbosa-Silva TG, Menezes AM, Bielemann RM, Malmstrom TK, Gonzalez MC. Enhancing SARC-F: Improving sarcopenia screening in the clinical practice. J Am Med Dir Assoc. 2016;17(12):1136-41.
15. Rosa TEC, Benício MHDA, Latorre MRD, Ramos LR. Fatores determinantes da capacidade funcional entre idosos. Rev Saude Publ. 2003;37:40-8.

16. Fiedler MM, Peres KG. Capacidade funcional e fatores associados em idosos do Sul do Brasil: um estudo de base populacional. Cad Saude Publica. 2008;24:409-15.

17. Duarte YAO. Desempenho funcional e demandas assistenciais. In: Lebrão ML, Duarte YAO. 0 projeto SABE no município de São Paulo: uma abordagem inicial. Brasília: Organização Pan-Americana da Saúde; 2003. p. 183-200.

18. Fisher AL. Of worms and women: sarcopenia and its role in disability and mortality. J Am Geriatr Soc. 2004;52(7):1185-90.

19. Reid KF, Naumova EN, Carabello RJ, Phillips EM, Fielding RA. Lower extremity muscle mass predicts functional performance in mobility-limited elders. J Nutr Health Aging. 2008;12(7):493-8.

20. Cuoco A, Callahan DM, Sayers S, Frontera WR, Bean J, Fielding RA. Impact of muscle power and force on gait speed in disabled older men and women. J Gerontol A Biol Sci Med Sci. 2004;59(11):1200-6.

21. Sowers MR, Crutchfield M, Richards K, Wilkin MK, Furniss A, Jannausch M, et al. Sarcopenia is related to physical functioning and leg strength in middle-aged women. J Gerontol A Biol Sci Med Sci. 2005;60(4):486-90.

22. Al Snih S, Raji MA, Peek MK, Ottenbacher KJ. Pain, lower-extremity muscle strength, and physical function among older Mexican Americans. Arch Phys Med Rehabil. 2005;86(7):1394-400.

23. Akune T, Muraki S, Oka H, Tanaka S, Kawaguchi $H$, Nakamura K, et al. Exercise habits during middle age are associated with lower prevalence of sarcopenia: the ROAD study. Osteoporos Inter. 2014;25(3):1081-8.

24. Liao ZY, Chen JL, Xiao MH, Sun Y, Zhao YX, Pu D, et al. The effect of exercise, resveratrol or their combination on Sarcopenia in aged rats via regulation of AMPK/ Sirt1 pathway. Exp Gerontol. 2017;98:177-83. 
25. Queiroz LCS, Bertolini SMMG, Bennemann RM, Silva ES. Efeito da prática do pilates solo na massa muscular de mulheres idosas. Rev Rene. 2016;17(5):618-25.

26. Marés G, Oliveira KB, Piazza MC, Preis C, Neto LB. A importância da estabilização central no método pilates: uma revisão sistemática. Fisioter Mov. 2017;25(2):445-51.

27. Nogueira TRB, Oliveira GL, Perini-de-Oliveira TA, Pagani MM, Valentim-Silva JR. Efeitos do método pilates nas adaptações neuromusculares e na composição corporal de adultos jovens. Rev Bras Presc Fisiol Exerc. 2014;8(45):296-303.

28. Papa EV, Dong X, Hassan M. Resistance training for activity limitations in older adults with skeletal muscle function deficits: a systematic review. Clin Interv Aging. 2017;12:955-61.

29. Souza SS Jr, Azevedo Guimarães AC, Korn S, Boing L, Machado Z. Força de membros superiores e inferiores de idosas praticantes e não praticantes de ginástica funcional. Saude (Santa Maria). 2015;41(1):255-62.

30. Santos Coelho B, Souza LK, Bortoluzzi R, Roncada C, Tiggemann CL, Dias CP. Comparação da força e capacidade funcional entre idosos praticantes de musculação, hidroginástica e não praticantes de exercícios físicos. Rev Bras Geriatr Gerontol. 2014;17(3):497-504.
31. Oliveira LC, Pires-Oliveira DA, Abucarub AC, Oliveira LS, Oliveira RG. Pilates increases isokinetic muscular strength of the elbow flexor and extensor muscles of older women: a randomized controlled clinical trial. J Bodyw Mov Ther. 2017;21(1):2-10.

32. Mendes PMV, Santos LE, Andrade Mesquita LS, Carvalho FT. Análise da funcionalidade e flexibilidade de mulheres em exercícios de pilates no solo. Arq Cien Saude. 2015;22(3):53-7.

33. Pestana MC, Pestana AMS, Pestana VS, Schinoni MI. Comparação entre os exercícios baseados no pilates solo versus exercício resistido sobre a marcha e equilíbrio do idoso. Rev Cienc Med Biol. 2014;12(4):441-8.

34. Cunha BS, Souza CRG, Prudente LOB, Osório NB, Silva Neto LS. Sarcopenia em idosas quilombolas: análise das variáveis antropométricas e de força de preensão manual. Rev Pat Tocantins. 2017;4(3):9-15.

Received in 08/08/2018

Recebido em 08/08/2018

Recibido en 08/08/2018

Approved in 03/07/2019 Aprovado em 07/03/2019

Aprobado en 07/03/2019 